УДК 371.3::[811.163.41+82

https://doi.org/10.18485/kij.2018.65.1_2.13

САША С. ЧОРБОЛОКОВИТ ${ }^{*}$

Основна школа „3. октобар”

Бор

\section{БИљАНА В. НИКИТ}

Народна банка Србије, Београд
Оригинални научни рад

Примљен: 27. 03. 2018.

Прихваћен: 26. 05. 2018.

\title{
ПРОПОРЦИЈЕ У НАСТАВИ СРПСКОГ ЈЕЗИКА И КЬИЖЕВНОСТИ У СТАРИЈИМ РАЗРЕДИМА ОСНОВНЕ ШКОЛЕ
}

\begin{abstract}
У раду се разматра употреба пропорција у настави српског језика и књижевности у старијим разредима основне школе. Основни циљ рада је приказати један од функционалних приступа настави матерњег језика кроз састављање и решавање пропорција. Задаци рада су следећи: указати на значај решавања пропорција, показати да је градиво српског језика погодно за њихово састављање (језик, књижевност, језичка култура) и да оне имају широку могућност примене - највише на часовима утврђивања у редовној настави, али и на часовима додатне наставе. Рад нуди и двојаку класификацију пропорција: према садржају (вербалне, сликовне и вербално-сликовне) и према броју одговора који недостају и њиховом типу (недостаје један одговор или два одговора; отворени или понуђени одговор). Решавањем пропорција ученици увежбавају логичко размишљање, повезују градиво различитих области српског језика, као и градиво различитих предмета, самостално откривају односе између појмова и закључују, при чему њихово знање постаје трајније и функционалније.
\end{abstract}

Кључне речи: пропорције, српски језик и књижевност, настава, методика.

Увод

Непосредни подстицај за писање овог рада ${ }^{1}$ јесте анализа резултата постигнутих на Завршном испиту из математике у школској 2014/2015. години у Основној школи „Војвода Мишић” у Београду. На седници Наставничког већа наставници математике су, анализирајући резултате, изнели занимљива запа-

\footnotetext{
*saleprof@gmail.com

${ }^{1}$ Радионицу Пропорције у настави српског језика и књижевности одржали смо на 59. Републичком зимском семинару за наставнике и професоре српског језика и књижевности, 8. фебруара 2018. године, на Филолошком факултету у Београду. О пропорцијама као игроликој активности у настави говорили смо на међународном симпозијуму Холипри, у Пироту, 14. октобра 2017. године.
} 
жања. Саопштили су да је најмањи број ученика тачно урадио задатке текстуалног типа (знатан број ученика није ни покушао да их реши) - задатке у којима проблем није нумерички постављен, већ ученик сам треба да пронађе начин на који ће задатак поставити и решити. Детаљнијом анализом утврђено је да су у решавању оваквих задатака успешнији били ученици који су имали тројке из математике од ученика који су имали петице. Пошто смо се до тада бавили задацима који подстичу функционално знање и логичко размишљање и примењивали их на нашим часовима, запазили смо да се наведени закључак наставника математике у великој мери подударио и са стањем на часовима српског језика - приликом коришћења асоцијација, мозгалица, ребуса и сличних задатака, често су „бриљирали” ученици који немају највише оцене из српског језика. ${ }^{2}$ О чему се овде заправо ради? Ученици који имају највише оцене најчешће су вредно научили шаблоне за решавање задатака (увежбали су њихове типичне моделе). Чим таквог шаблона нема, они не умеју самостално да пронађу начин за решавање задатка. С друге стране, ученици који имају тројке углавном нису научили шаблоне, па их они и не спутавају у решавању задатака који захтевају креативни приступ, због чега су и успешнији у томе.

Дакле, анализа резултата Завршног испита из математике показала је да ученици не умеју да примене научено, између осталог, и зато што је меморисање чињеница (учење напамет) и даље најзаступљенија техника учења и врло чест критеријум за процену знања у нашим школама ${ }^{3}$, иако се многи аутори слажу у томе да би савремена настава требало да тежи оспособљавању ученика да властитим интелектуалним напорима долазе до сазнања (Ивић и др. 1997; Јукић 2001). Репродуктивно знање не активира више мисаоне процесе, не развија креативност, самосталност ни мотивацију ученика, а нарочито не одговара реалним животним ситуацијама и потребама савременог друштва. Иако је у данашње време ученицима потребна холистичка слика изучаване појаве, корелација међу предметима своди се на ангажовања појединих наставника, уместо да то буде удружени тимски рад и системски план у школи.

Један од начина који би поменуте недостатке могао да ублажи и омогући бољу наставу јесте коришћење задатака који захтевају логичко размишљање и којима се остварује унутарпредметна и међупредметна корелација. Сматрамо да коришћење пропорција може бити изузетно делотворно у мисији превазилажења наведених потешкоћа у нашим школама и заокрета наставе српског језика ка функционалном приступу.

${ }^{2}$ Искуство стечено на часовима помогло нам је у писању два приручника - Acouиjације у настави српског језика и књижевности и Квизови у настави српског језика и књижевности (Ломпар и др. 2014; Ломпар и др. 2017). Том приликом нарочиту пажњу смо обратили на међупредметну корелацију, функционалност онога што се учи и тежњу да градиво учинимо животним тиме што смо га повезали са искуством и интересовањима ученика.

${ }^{3}$ На овакво, лоше стање у нашим школама упозорио је Баковљев још 1982. године (Баковљев 1982), али до великих и суштинских промена до дана данашњег није дошло. Од новијих радова погледати Драгићевић (2012). 
Предмет овог рада је примена пропорција у настави српског језика. Циљ рада је показати зашто су пропорције корисне за наставу српског језика у старијим разредима основне школе, а задаци рада су приказати како се пропорције могу користити у настави српског језика, у којим областима их је погодно користити, у којим временским деоницама и типовима часова, и шта се њиховом употребом на часу постиже.

\section{Пропорције у основношколској настави и психолошкој литератури}

Пропорције представљају једнакост двају односа између величина или уопште између одређених појмова. Уобичајено, пропорција има четири члана.

Пропорцијама припада значајно место у настави многих наставних предмета у старијим разредима основне школе. Најширу и најпознатију примену имају у математици за седми разред, у области Примена пропоричоналности (Икодиновић, Димитријевић 2011: 115-120), с тим да се о размери учи и у петом и шестом разреду. Пропорције се користе у физици у шестом разреду, приликом учења о Узајамном деловағу тела (Стевановић, Крнета 2008: 71), и у хемији у седмом разреду, при обради наставне јединице Процентни састав раствора (Анђелковић, Недељковић 2009: 129). Ако овоме додамо примену пропорција на часовима географије - приликом учења о размери у петом разреду, у оквиру наставне јединице Математички елементи карте (Јоксимовић и др. 2012: 39-40) и ликовне културе - приликом цртања и сликања у седмом разреду (Пропоричие, Глигоријевић 2012: 16-25), јасно се уочава да пропорције имају много ширу примену од оне општепознате на часовима математике.

Употребу пропорција као типа логичког задатка подржава и психолошка литература. Логичке пропорције се већ деценијама примењују у психолошким тестовима. Наш психолог Борислав Стевановић (2010) у вербалној серији тестова интелигенције, које је саставио и штампао 1931. године, предвидео је и задатке вербалних пропорција. Вербална серија тестова састоји се од пет подтестова, а један од њих је закључивање по аналогији, задато у облику пропорције - дат је пар речи које су у одређеном односу, а задатак испитаника је да на основу аналогије пронађе међу понуђеним речима ону која правилно допуњава пропорцију. Дакле, Стевановић је сматрао да се на основу способности решавања пропорција може предвидети општа интелектуална способност, тј. да се на основу резултата ових тестова може предвидети успех у школи и у каријери, нарочито у занимањима која захтевају развијене комуникацијске и вербалне вештине. С друге стране, ако знамо да се интелигенција може развијати искуством и учењем, јасно је да увежбавање решавања оваквих задатака доприноси општим интелектуалним способностима.

И теорија интелектуалног развоја швајцарског психолога Жана Пијажеа (према Миочиновић 2002) подржава употребу пропорција, односно размишљања 
у аналогијама. Творац једне од најпознатијих теорија когнитивног развоја идентификовао је четири стадијума развоја интелигенције - сензомоторни период, преоперациони период, период конкретних операција и период формалних операција. Стадијум формалних операција, који према Пијажеу наступа око 11-12. године детета, између осталог, подразумева да дете може да закључује на основу аналогије, тј. да може размишљати у пропорцијама. Пре овог стадијума деца могу да размишљају о ономе што је реално и могуће, а у стадијуму формалних операција дете може да размишља дедуктивно-хипотетички, да се бави комбинаториком и сл. Даље, Жан Пијаже је утврдио да дете, када досегне одређени период когнитивног развоја, усвојену схему размишљања воли да увежбава. Тако, на пример, када му се на стадијуму конкретних операција јави структура груписања (серијација, класификација, кореспонденција), дете воли да сакупља разне ствари (сличице, салвете и сл.) и да их класификује, на тај начин увежбавајући усвојену схему. С обзиром на то да друштвена средина не може стварати когнитивне структуре, али може да убрза или успори развој појединца, како је Жан Пијаже утврдио, веома је важно да средина буде подстицајна за дететов развој. Сматрамо да је решавање пропорција у наведеном узрасту веома важно не само зато што дете тада треба да увежба и учврсти нову схему размишљања већ и зато што у том периоду дете воли да решава такве задатке, што јача његову мотивацију. Међутим, иако је дете у 11-12. години усвојило схему размишљања у аналогијама, наш школски систем не пружа довољно прилике да ученици те способности увежбају и унапреде.

Дакле, психолошка литература не само да подржава употребу пропорција као начина за усвајање и увежбавање једне схеме размишљања, употребљиве у многим областима и у животу, већ и доказује да је нарочито подесно за когнитивни развој детета користити их у старијим разредима основне школе.

\section{Врсте пропорција (могућа класификација)}

Док је у директном класичном питању јасно наглашено шта се захтева од ученика, у пропорцијама ученик треба да посматра дати пар појмова, промишљањем да уочи какав однос постоји међу њима, а затим да тај однос пренесе на други пар речи и тако пронађе решење. Пропорцијама се, дакле, не испитује само да ли ученик познаје чињенице него и његова способност да мисли и закључује. Од те способности зависи његов целокупни школски успех, а и каснији животни успех, па би требало да задатак савремене наставе буде оспособљавање ученика за целоживотно учење и сналажење у новим и непознатим ситуацијама.

Разлика између класичног питања и пропорције, који захтевају исти одговор приказана је у табели: 
Табела 1. Упоредни приказ класичног питаға и пропоријије

\begin{tabular}{|l|l|}
\hline \multicolumn{1}{|c|}{ Класично питање } & \multicolumn{1}{c|}{ Пропорција } \\
\hline $\begin{array}{l}\text { Напиши 2. лице једнине импера- } \\
\text { тива глагола открити. }\end{array}$ & $\begin{array}{l}\text { Шта треба да стоји уместо знака питања? } \\
\text { наћи : нађи = открити : ? }\end{array}$ \\
\hline
\end{tabular}

Ако упоредимо питања из табеле, видимо да класично питање захтева од ученика примену знања о глаголским облицима - ученик треба да глагол откри$m u$ наведе у траженом глаголском облику, лицу и броју, док питање у виду пропорције захтева исто то, али на другачији начин - ученик из првог пара примера треба да схвати да је реч о инфинитиву и императиву глагола, и да на правилан начин допуни други пар речи. Притом, решавајући пропорције, ученик не мора да познаје одговарајуће граматичке термине јер се од њега захтева функционално знање, језик у употреби.

Пропорције се могу поделити на основу два критеријума - према садржају и према типу одговора.

Када је у питању садржај пропорције, однос у њој се може задати речима, сликама или комбиновано - речима и сликама. Сходно томе, можемо говорити о вербалним, сликовним и мешовитим, вербално-сликовним пропорцијама. Навешћемо по један пример за сваку наведену врсту пропорција.

\section{1. Вербалне пропорције}

низак : нижи = висок : (виши)

Коментар: Ученик треба да уочи однос у коме се налазе прве две речи - позитив и компаратив, и да га пренесе на други пар примера допуњујући пропорцију. Компаратив виши изабран је не само зато што би требало да ученици увежбају компарацију као категорију придева и прилога већ и да би се указало на његов правилан облик, с обзиром на то да се међу говорницима српског језика често могу чути неисправни облици *вишљи и *височији.

\section{2. Сликовне пропорције}
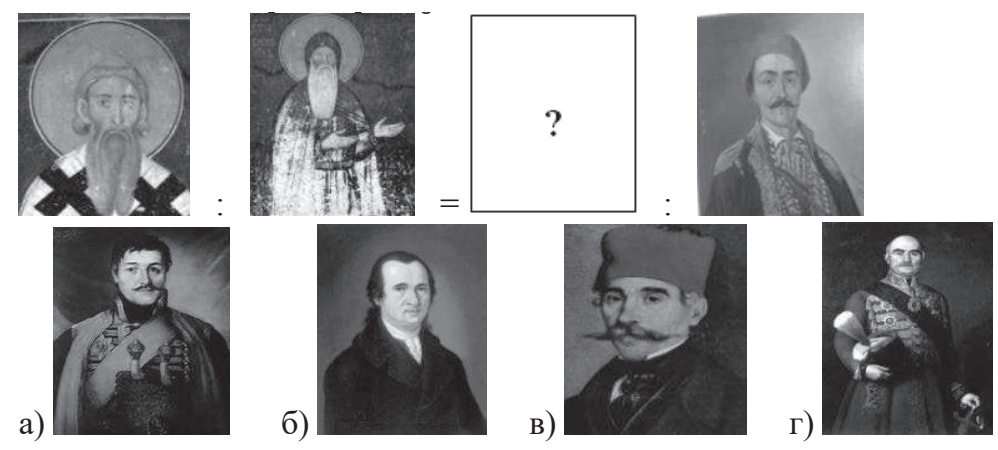

(Решење: в) 
Коментар: У датој пропорцији ученик треба да одгонетне који однос постоји међу личностима у првом пару како би други пар допунио одговарајућом сликом. На основу првог пара слика ученик би могао помислити да на други пар личности треба пренети однос син-отац. Међутим, пошто проучи понуђене одговоре, схвата да је однос који се тражи у ствари биограф и личност о којој је он писао (као што је Свети Сава писао о свом оцу Стефану Немањи, тако је Вук Караџић написао биографију Хајдук Вељка Петровића).

\section{3. Вербално-сликовне пропорције}

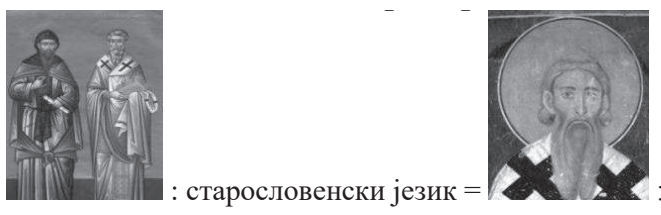
(српскословенски језик)

Коментар: Ученик, на основу слике Ћирила и Методија и речи старословенски језик, уочава однос дат у првом пару, а то је личност - књижевни језик који је она користила, па други пар допуњава речима српскословенски језик.

Други критеријум на основу ког смо поделили пропорције јесте тип одговора. У пропорцијама може недостајати један одговор или могу недостајати два одговора. Када недостаје један одговор, он може бити понуђен или отворен. Када недостају два одговора, они морају бити понуђени, а то се може учинити давањем парова одговора или навођењем две групе одговора, из којих ученик треба да изабере по један и тако исправно формира пропорцију. Навешћемо примере за описане типове пропорција.

\section{1. Недостаје један одговор}

a) понуђени одговор

рука : ручица = нога :

а) ногица б) ножица в) ножни г) ножурда (Решење: б)

Коментар: Наведени пример показује да се пропорције могу решити коришћењем знања из више области српског језика (овде: лексикологије, творбе речи и/или фонетике) и да није оправдано строго их разграничавати при језичким вежбањима. Анализом првог пара примера ученик закључује у ком су творбеном односу дате речи, па ће тај однос пренети и на други пар примера. Иако су овде одговори понуђени, они знатније не олакшавају решавање задатка будући да је међу понуђеним нетачним одговорима и изузетан ометач - именица ногиuุ. Ученик ће запазити да у примеру ручица деминутивно значење преовладава над хипокористичним (за разлику од примера рукиияа), па ће реч у другом пару допунити именицом која је претежно деминутив, именицом ножица. ${ }^{4}$ Осим на

${ }^{4}$ Кажемо да је нешто претежно деминутив односно хипокористик (и исто тако за аугментатив и пејоратив), јер је разлику међу њима често тешко одредити (у прилог овој тврдњи говори и лексикографска пракса, у којој се много чешће речима додељује квалификација дем. и хип., односно аугм. 
овај начин, ученици задатак могу решити и помоћу знања из фонетике - као што је у другој речи првог пара извршена палатализација, и у другој речи другог пара треба изабрати облик са извршеном палатализацијом.

\section{б) отворени одговор}

донети : донесен $=$ доносити : (доношен)

Коментар: Да би се наведени пример решио, треба познавати морфологију, фонетику и правопис српског језика. Треба уочити да је у првом пару речи дат однос инфинитив глагола према глаголском придеву трпном истог глагола (у мушком роду једнине), па у складу с тим треба допунити други пар речи, водећи рачуна о норми српског језика.

\section{2. Недостају два одговора}

\section{a) понуђени су парови тачних одговора}

K : $=ч:$

а) палатализација, сибиларизација

б) задњонепчани, предњонепчани

в) звучни, безвучни

г) г, ђ

(Решење: б)

Коментар: У наведеном примеру дати су парови одговора, међу којима треба пронаћи онај који правилно допуњава пропорцију. На основу понуђених одговора ученик схвата да пропорцију може правилно допунити према критеријуму поделе гласова по месту творбе, а да остали понуђени одговори не би градили исти однос у оба пара примера.

\section{б) понуђени су одговори које треба упарити}

штампати: $=$

: дизалица
1) штампач
2) штампар
3) одштампати
4) штампање
а) дизање
б) подићи
в) дизач
г) дизати (Решење: 1г)

Коментар: Наведени задатак користио би се за увежбавање градива о творби речи. На основу речи дизалица ученик схвата да први пример треба допунити називом за оруђе (nomina instrumenti), па први пример допуњава речју штамnач. Затим други пример допуњава глаголом дизати на основу глагола у првом примеру.

\section{Пропорције у настави српског језика и књижевности}

Иако нису све области српског језика и књижевности подједнако погодне за коришћење пропорција, нема ниједне у којој се пропорције не могу функционално користити у настави. Коришћење пропорција нарочито је погодно за

u nеј., него што им се додељује само једна од њих). Употреба ових облика у вези је с говорниковом намером и комуникативним циљевима. Тако, у типичном случају, деминутив изражава позитиван став говорника према ономе о чему говори, па га често прати и хипокористичност, док аугментатив, типично, изражава негативан говорников став, па га често прати и пејоративност (Јовановић 2010: 27). 
увежбавање градива из граматике, јер сама форма пропорција онеобичава класична питања и постаје својеврсна загонетка, мозгалица коју ученици треба да одгонентну и реше.

Показаћемо на примерима како се пропорције могу користити у свим областима српског језика и књижевности.

У фонетици пропорције се могу користити за увежбавање класификације гласова и гласовних промена. Навешћемо примере.

- $3: \mathrm{c}=6$ : (п)

- Славка : $=$ : Славичин
1) Славкин
2) Славчин
3) Славичин
4) Славицин
a) Славичица б) Славољуб
в) Славица
г) Славка (Решење: 1в)

- $\quad$ Америка : Америци = Мека :

- благ : строг = блажи :

- $\quad$ певати : отпевати = свирати : (Меки)

У пропорцијама с гласовним променама пожељно је користити примере који се често употребљавају у погрешним облицима ( ${ }^{*}$ Славищин, *Меци, * жији, *отсвирати и сл.), јер учење граматичких правила изоловано од праксе нема никаквог смисла. Зато су пропорције с примерима сличним наведеним одличан начин да се покаже да се „нормативно не сме одвајати од функционалног - они морају да се преплићу, да постоје у непрекидној узајамности” (Милатовић 2013: 376).

У морфологији можемо користити пропорције следећег типа:

- $\quad$ Capa : Capo = Tapa :

- изнад : (Tapa)
a) над, генитив
б) горе, генитив
в) над, инструментал
г) преко, локатив (Решење: в) $=$ генитив :

- $\quad$ пишући : писати = дајући : (давати)

- $\quad$ над : изнад $=$ под :

- $\quad$ два : оба = двоје : (испод)

Као што се из примера види, пропорцијама се могу увежбавати и променљиве и непроменљиве врсте речи. Њима можемо циљано вежбати оне категорије које ученици теже запамте, као и указивати на правилне облике код којих матерњи говорници често греше (у датим примерима то је вокатив двосложних женских имена и глаголски прилог садашњи).

Творба речи је једна од језичких области српског језика у којој се пропорције могу најсврсисходније употребити. У традиционалној настави и уџбеничкој литератури која је прати углавном се инсистира на разврставању речи по постанку (на просте и творенице, и даља подела твореница на изведенице и сложенице). Поменуто разврставање најчешће се обавља строго формалном анализом, идентификовањем и издвајањем творбених форманата, због чега их ученици врло често уче напамет, без разумевања значењских веза између мо- 
тивне и мотивисане речи. Сматрамо да анализа творбеног значења мора бити један од најважнијих задатака наставе творбе речи, а то се може веома ефикасно постићи пропорцијама:

- шљива : шљивик = малина : (малињак)

- град : = село :
1) градић
2) саградити
3) градитељ
4) градски
а) сељак
б) сеоце
в) населити
- $\quad$ сова : совица = миш : (мишић) = читати : прочитати

г) сељаков (Решење: 1б)

- радити :
а) прорадити
б) зарадити
в) урадити
г) порадити (Решење: в)
- $\quad$ граничити : граничник = слушати : (слушалица)

Пропорције могу много пружити код постојања хомонимних суфикса:

- $\quad$ крава : кравица = слон : (слонче)

- $\quad$ лав : лавица = слон (слоница).

У задатку је употребљен суфикс -ица, који спада у најпродуктивније суфиксе у нашем језику. ${ }^{5}$ Од ученика се очекује да воде рачуна о значењу речи приликом решавања оваквог задатка јер је оно кључно за проналажење тачног одговора.

Избегавањем строго формалног приступа у творбеној анализи речи, творби речи се даје практичан значај и ученици виде смисао онога што уче. Оваквим приступом ученицима показујемо и то да се речи за нове појмове које нам недостају у језику могу саградити „коришћењем језичког материјала нашег језика, а не позајмљивањем страних речи” (Драгићевић 2012: 97).

У лексикологији се пропорције могу користити за увежбавање значењских односа међу речима (антоними, хипероними и хипоними, речи субјективне оцене и сл.), затим за скретање пажње на употребу домаћих речи уместо позајмљеница, а могу бити и одлична лексичка вежба се богаћење речника:

- $\quad$ ући : изаћи = дошетати : (одшетати)

- $\quad$ ружа: цвет = столица : (намештај)

- $\quad$ федер : опруга = штекер :
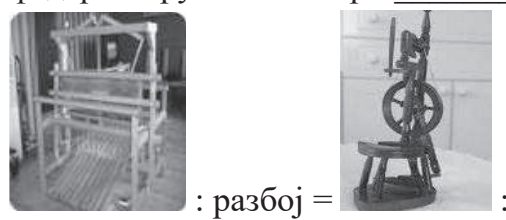
(утикач)

- $\quad$ Никола : Николетина = Пилип (преслица)

Најтеже је осмислити примере за примену пропорција у синтакси, с обзиром на то да су за пропорције, због уочавања логичког односа у њима, погод-

5 Детаљно о овом суфиксу, о његовим различитим значењима који су условљени семантичким потенцијалом творбене основе говори Клајн (2003: 113-119). 
нији краћи примери, а синтакса углавном захтева реченицу, ако не и шири текст. Међутим, пажљивим промишљањем успели смо да пронађемо примере за примену пропорција у настави синтаксе за које сматрамо да би у раду са ученицима били сврсисходни:

- Никола јури пса. : Николу јури пас. = Милош воли мачку. :

(Милоша воли мачка.)

- $\quad$ Разбили су прозор. : Прозор је разбијен. = Прочитали су књигу. $=$ (Књига је прочитана.)

- $\quad$ Марко је победио : Марко је био први. = Марко глуми. : (Марко је глумац.)

- $\quad$ кућа мога деде : дедина кућа = кућа жуте боје : (жута кућа).

Сматрамо да су наведени задаци функционални јер захтевају употребу језика, о којој се у нашим школама мало или никако не води рачуна. У наставној пракси често се инсистира на класификацији одређених језичких појава, а не и на употреби језика, контекстуализацији, која „обезбеђује бољу мотивисаност, јер ученик захваљујући њој препознаје смисао изучавања језичке појаве и оспособљава се за увићање веза са већ познатим садржајима” (Вељковић Станковић 2010: 10).

Историја језика и дијалекти је област српског језика веома погодна за коришћење пропорција. Ова област српског језика захтева памћење чињеница, па је стога потпуно смештена у основни ниво образовних стандарда: CЈ.1.3.17. - разликује појмове кьижевног и народног језика; зна основне податке о развоју кьижевног језика код Срба (од почетака до данас); CJ.1.3.18. - зна основне податке о пореклу и дијалекатској разуђености српског језика; СЈ.1.3.19. - зна основне податке о језицима нациионалних мағина (Марчетић и др. 2010). Међутим, резултати писмених провера из ове области, као и резултати завршних испита, не показују да ученици у овој области остварују успех очекиван за прописани ниво постигнућа. Меморисање чињеница ученицима делује заморно, па је неопходно и потпуно оправдано репродуктивно знање учинити занимљивијим тако што ћемо чињенице доводити у различите логичке везе да би их ученици трајно запамтили. Притом, препоручљиво је и коришћење слика, како би ученици и визуелно запамтили оно што уче. На пример: 
- $\quad$ Прво издање Српског рјечника : Јернеј Копитар = Друго издање Сpnског рјечника : (Ђуро Даничић)

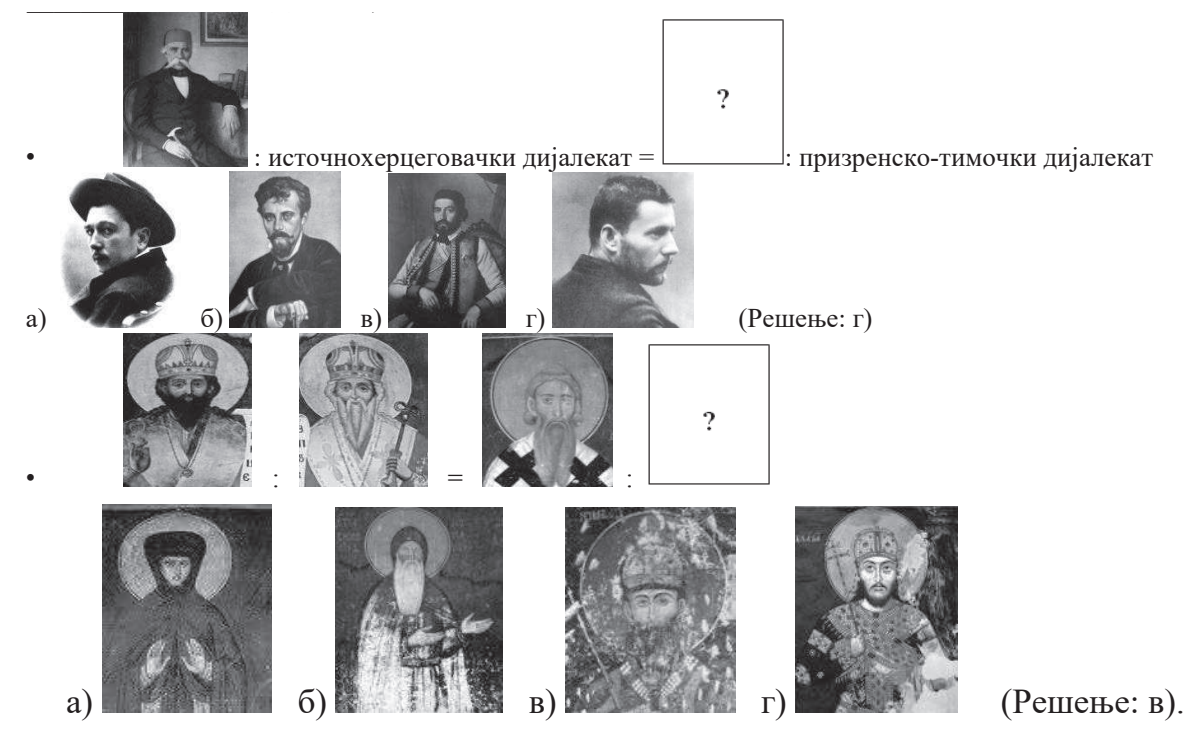

Овакви задаци се могу учинити и сложенијим, изостављањем још једног члана пропорције. Тада је, да би се решио задатак, потребно понудити два низа одговора.

: Писменицุа $=$ : Српске народне пословице

1) 1814. година 2) граматика 3) азбука Саве Мркаља 4) Пјеснарица
a) Петар Петровић Његош б) Цетиње в) речник г) 1836. година (Pe- шење: $1 г)$.

Често се овакво, чињенично градиво памти без икаквог промишљања - на тестовима и при одговарањима ученици често журе да одговоре иако још није постављено питање. И аутори задатака у радним свескама, збиркама и тестовима који постоје на тржишту нуде врло слична питања везана за ову област, као да сматрају да проверавање тога колико су ученици чињеница запамтили значи и ограничен број питања и не оставља простор за било какву новину. Зато је добро у пропорције поставити однос за који ученици не очекују да ће бити испитиван (нпр. последња сликовна пропорција може се тачно допунити само проналажењем слике Стефана Првовенчаног, брата Светог Саве).

Правопис, по својој природи, није нарочито погодан за коришћење пропорција, будући да углавном подразумева увежбавање правилног писања. Међутим, и у тој области могу се успешно применити пропорције: 
- _
1) будизам
2) католичанство
3) ислам 4) Ислам
a) Исус
б) Бог
в) бог
г) православље (Решење: 3б)
- Велики медвед : сазвежђе = велики медвед : (животиња)
- Август : цар = август : (месец)
- Фијатови аутомобили : фијат = Рендгенов апарат :
- $\quad$ научити : научићемо = рећи : (рећи ћемо). (рендген)

Оваквим правописним вежбама негује се учење с разумевањем и практична примена правописних правила, развија се и подстиче критичко мишљење ученика, нарочито важно у данашње време, када се под утицајем медија, пре свега интернета, развија непоштовање правописа и уопште свест о безначајности језичке културе. ${ }^{6}$ Коришћењем оних примера код којих се најчешће греши (овде нпр. писање месеци и дана у недељи великим почетним словом под утицајем енглеског језика, или грешке приликом састављеног/растављеног писања облика футура првог), указује се на то да треба развити критички однос према ономе што је написано на различитим натписима, које ученици почињу да преиспитују, не третирају их као ауторитет изнад Правописа, већ обрнуто.

Књижевност је погодна за коришћење задатака у облику пропорција. На овај начин могу се утврђивати књижевнотеоријска знања, али и знања о конкретним књижевним делима (ликови, место, време радње итд.). На пример:

- $\quad$ лирски субјекат : лирика $=$ : епика (приповедач)

- $\quad$ војвода Пријезда : Јелица = Дмитар Јакшић :

- $\quad$ браћа Јакшићи : Београд = Марко Краљевић : (Анђелија)

- $\quad$ кмет Симан : Ибрага = Кањош Мацедоновић :

- Анди: Динго = Лујо: (Прилеп)

- Јован Јовановић Змај : Ружа = (Јаблан) (Фурлан)

Овакви задаци за утврђивање градива из књижевности били би погодни као вежбање за такмичење на додатној настави, али и за само такмичење Књижевна олимпијада. Уместо питања у којима се захтева само пасивно познавање чињеница, затим оних која нису у директној вези с књижевним делом или пак питања у којима се тестира познавање неких детаља из књижевних дела небитних за њихово значење и тумачење (препознавање стилских фигура на примерима без тумачења њихове функције у тексту, одређивање значења речи неважних за главни смисао књижевног дела), могу се осмислити и употребити пропорције. Оне не би заузеле пуно простора (због чега се, вероватно, на тестовима избегавају дужи одломци), не би биле тешке за прегледање (због чега се избегавају одговори есејског типа), а вежбања односно такмичење били би квалитативно обогаћени новим типом питања, које је занимљиво, привлачи пажњу, мисаоно ангажује ученика, подстиче логичко размишљање и захтева повезивање више књижевних дела.

${ }^{6}$ О употреби јавних натписа с грешкама у настави правописа в. шире у Чорболоковић (2015). 
Из наведених примера јасно је да се пропорције могу користити и у редовној настави, али, још и више, у додатној настави, с обзиром на то да пропорције активирају више нивое мишљења. Уосталом, математички текстуални задаци поменути на почетку рада припадају напредном нивоу постигнућа ученика, па су зато готово једини тип задатака на математичким такмичењима. То, наравно, не значи да ученици са слабијим нивоом постигнућа неће моћи да реше овакве задатке, прво зато што пропорције често позивају ученика на „здраву логику”, а тек онда (а можда ни тада) на конкретна знања из неког предмета, а друго стога што учесталијим коришћењем оваквих задатака, без обзира на то што су у њима постављени различити односи међу појмовима, ученици ипак увежбавају њихово решавање.

Уз све предности употребе пропорција, осећај за меру је врло битан, јер и најзанимљивија активност на часу постаје обична ако се често употребљава, па самим тим и очекивани ефекат изостаје.

\section{Закључак}

У раду је разматрана примена пропорција у настави српског језика и књижевности. На основу описаних и коришћених примера у настави старијих разреда основне школе, може се закључити следеће:

1. Градиво из наставног плана и програма за српски језик у старијим разредима основне школе погодно је за састављање пропорција - њиховом применом могу се остварити очекивани исходи и стандарди постигнућа ученика.

2. Пропорције се могу везати за све области српског језика (језик, књижевност и језичка култура) и највише се примењивати на часовима утврђивања градива.

3. Могу се користити у свим облицима рада - групном раду, раду у пару, индивидуалном и фронталном облику рада.

4. Применљиве су у уводном, оперативном и завршном делу часа, с тим да сматрамо да су нарочито ефектне у уводном делу часа, када наставник оваквом врстом „мозгалице” придобија пажњу ученика и успешно их уводи у нову наставну јединицу.

5. Могуће је саставити више типова пропорција: вербалне, сликовне и вербално-сликовне пропорције, као и пропорције с једном непознатом и с две непознате, с понуђеним одговорима и без њих.

6. Коришћењем пропорција, ученици вежбају да логички размишљају, да самостално откривају односе међу појмовима и закључују, што би требало да побољша успех и у другим школским предметима.

7. Иако се на први поглед чини да су пропорције један тип задатка, оне то нису, с обзиром на то да је у свакој пропорцији дат другачији однос међу појмовима, па се оне не решавају шаблонски. 
8. Пропорцијима се реорганизују постојећа сазнања, а нова се интегришу у целовитије и повезаније мисаоне структуре.

9. Пропорције много чешће него класична питања захтевају употребу језика (а не теоријска знања), па ученици, увиђајући функционалност онога што уче, повећавају и своју мотивисаност за усвајање знања.

10. Пропорције увежбавају ученике да мисле, односно да се сналазе у новим, непознатим ситуацијама, што би требало да је један од главних задатака савремене школе, с обзиром на то да се ученици припремају за занимања и изазове који су данас непознати, а који ће се појавити с убрзаним технолошким развојем друштва.

\section{АНАЛИЗИРАНИ УЏБЕНИЦИ}

Анђелковић, Недељковић 2009: Д. Анђелковић, Т. Недељковић, Хемија 7. Збирка задатака са решенима из хемије за седми разред основне иколе, Београд: Логос.

Глигоријевић 2012: Ј. Глигоријевић, Ликовна култура 6, Београд: БИГЗ.

Икодиновић, Димитријевић 2011: Н. Икодиновић, С. Димитријевић, $M a-$ тематика 7. Уибеник за седми разред основне школе, Београд: Клет.

Јоксимовић и др. 2012: М. Јоксимовић, Н. Бировљев и С. Поповић, Географија 5. Уибеник географије за пети разред основне школе, Београд: Логос.

Стевановић, Крнета 2008: К. Стевановић, М. Крнета, Физика 7. Уибеник за седми разред основне школе, Београд: БИГЗ.

\section{ЛИТЕРАТУРА}

Баковљев 1982: М. Баковљев, Мисаона активизација ученика у настави, Београд: Институт за педагошка истраживања, Просвета.

Вељковић Станковић 2010: Д. Вељковић Станковић, Комуникативни приступ у настави српског језика, Узданища, VII/1, Јагодина, 7-17.

Драгићевић 2012: Р. Драгићевић, Лексикологија и граматика у школи, Београд: Учитељски факултет Универзитета у Београду.

Ивић и др. 1997: И. Ивић, А. Пешикан, С. Јанковић и С. Кијевчанин, $А \kappa-$ тивно учење: приручник за примену активних метода наставе/учења, Београд: Институт за психологију. 
Јовановић 2012: В. Јовановић, Деминутивне и аугментативне именице у српском језику, Београд: Институт за српски језик САНУ.

Јукић 2001: S. Jukić, Nastava u kojoj učenik misli, Vršac: Viša škola za obrazovanje vaspitača.

Клајн 2001: И. Клајн, Творба речи у савременом српском језику. Део 2, Суфиксација и конверзија, Београд: Завод за уџбенике и наставна средства - Институт за српски језик САНУ; Нови Сад: Матица српска.

Ломпар и др. 2014: В. Ломпар, Ј. Живановић, Н. Кљајић, М. Марковић, Б. Никић и С. Чорболоковић, Асоцијаџије у настави српског језика и кюижевности: приручник за наставнике, Београд: Клет.

Ломпар и др. 2017: В. Ломпар, Ј. Живановић, Н. Кљајић, М. Марковић, Б. Никић и С. Чорболоковић, Квизови у настави српског језика и кьижевности: приручник за наставнике, Београд: Клет.

Марчетић и др. 2010: А. Марчетић, А. Антић, А. Станић, Д. Иванић, К. Симић Мишић, Т. Жигић, Д. Кликовац, Ј. Московљевић Поповић, Т. Шофранац, 3. Мркаљ, С. Јовановић, М. Рикало, Н. Кировски, С. Лакићевић и Д. Плут, Образовни стандарди за крај обавезног образовања за наставни предмет Српски језик, Београд: Завод за вредновање квалитета образовања и васпитања - Министарство просвете Републике Србије.

Милатовић 2013: В. Милатовић, Методика наставе српског језика и књижевности у млађим разредима основне школе, Београд: Учитељски факултет.

Миочиновић 2002: Љ. Миочиновић, Пијажеова теорија интелектуалног развоја, Београд: Институт за педагошка истраживања.

Стевановић 2010: Б. Стевановић, Вербална серија - приручник, Београд: Центар за примењену психологију.

Чорболоковић 2015: С. Чорболоковић, Јавни натписи са грешкама у настави правописа у основној школи (од 5. до 8. разреда), у: Имплементација иновација у образовању и васпитању - изазови и дилеме, Београд: Учитељски факултет, 457-471. 
Saša S. Čorboloković, Biljana V. Nikić

\title{
PROPORTIONS IN TEACHING SERBIAN LANGUAGE AND LITERATURE IN HIGHER GRADES OF PRIMARY SCHOOL
}

\begin{abstract}
Summary
The paper analyses the use of proportions in teaching the Serbian language and literature in higher grades of the primary school. The main goal of the paper is to demonstrate one of functional approaches to mother tongue teaching based on making and resolving of proportions. The tasks of the paper are the following: highlight the importance of resolving proportions, show that the Serbian language and literature subject matter is convenient for making proportions (language, literature, language competence) and that they are widely applicable - mainly in recapitulation classes in regular teaching, but also in advanced learner classes. The paper also offers a twofold classification of proportions: according to the content (verbal, visual imagery and verbal-visual imagery) and according to the number of responses missing and the type of response (one or two responses missing; open-ended or offered response). By resolving proportions pupils practice logical reasoning, make connections across different subject areas, both in the Serbian language course and across different courses, discover relations between different concepts on their own and derive conclusions, thus acquiring knowledge on a more permanent and functional basis.
\end{abstract}

Key words: proportions, Serbian language and literature, teaching, teaching method. 